\title{
Functional abilities in children with Cornelia de Lange syndrome - pilot study
}

\author{
Zdolności funkcjonalne dzieci z zespołem Cornelii de Lange - badanie pilotażowe \\ Emilia Mikołajewska (iD) \\ Department of Physiotherapy, Ludwik Rydygier Collegium Medicum in Bydgoszcz, Nicolaus Copernicus University in Toruń, \\ Poland
}

\section{ABSTRACT}

INTRODUCTION: Cornelia de Lange syndrome (CdLS, also called Brachmann de Lange syndrome - BdLS) is a congenital multisystem developmental disorder characterized by distinctive facial features, growth and mental retardation, limb abnormalities, and behavioral problems caused by various malformations. Despite the efforts of scientists, previous functional assessments were mainly focused on hearing and vision. The aim of the study was twofold: 1) to show the functional status of children with CdLS, 2) to propose a unified protocol/tool for the aforementioned assessment.

MATERIAL AND METHODS: 27 children with CdLS were assessed in terms of functioning and associated limitations using a questionnaire-aided interview and observational functional assessment.

RESULTS: The most common functional problems were contractures $(88.89 \%)$, deformities $(66.67 \%)$, and torso asymmetry $(66.67 \%)$.

CONCLUSIONS: The outcomes of the study show the functional status of children with CdLS. Even preliminary findings may shape a further holistic approach to treatment, rehabilitation and care. Moreover the proposed tool was useful. This study could be a good starting point to develop new protocols/tools applicable to such complex diseases. Moreover, further and wider studies are needed in order to allow a more complete and accurate assessment, thereby ensuring more efficient treatment plans.

\section{KEY WORDS}

Cornelia de Lange syndrome, Brachmann de Lange syndrome, function, behavioral phenotype

\section{STRESZCZENIE}

WSTĘP: Zespół Cornelii de Lange (Cornelia de Lange syndrome - CdLS, nazywany również Brachmann de Lange syndrome - BdLS) jest wrodzonym wielosystemowym schorzeniem rozwojowym, charakteryzującym się wyróżniającymi się rysami twarzy, opóźnieniem wzrostu i umysłowymi, anomaliami w obszarze kończyn oraz problemami behawioralnymi spowodowanymi deformacjami. Pomimo wysiłków naukowców, dotychczasowe próby oceny funkcjonalnej dzieci z CdLS koncentrowały się głównie na słuchu i wzroku. Cele badania były następujące: 1) przedstawić stan funkcjonalny dzieci z CdLS, 2) zaproponować jednolity protokół/narzędzie do jego oceny.

MATERIAŁ I METODY: Badaniu poddano 27 dzieci z CdLS, które oceniono pod kątem funkcjonowania i jego ograniczeń z wykorzystaniem kwestionariusza oraz badania obserwacyjnego.

Received: 01.07.2017 Revised: 11.10.2017 Accepted: 02.06.2019 Published online: 22.10 .2019

Address for correspondence: Dr hab. Emilia Mikołajewska, prof. UMK, Department of Physiotherapy, Ludwik Rydygier Collegium Medicum in Bydgoszcz, Nicolaus Copernicus University in Toruń, Poland, ul. Techników 3, 85-801 Bydgoszcz, tel. + 48725889 909, e-mail: e.mikolajewska@wp.pl; emiliam@cm.umk.pl Copyright @ Śląski Uniwersytet Medyczny w Katowicach www.annales.sum.edu.pl 
WYNIKI: Najczęściej spotykane problemy funkcjonalne dotyczyły przykurczy (88,89\%), deformacji (66,67\%) oraz asymetrii tułowia $(66,67 \%)$.

WNIOSKI: Wyniki badania pokazują stan funkcjonalny dzieci z CdLS. Nawet wyniki wstępne mogą kształtować dalsze całościowe podejście do leczenia, rehabilitacji i opieki w tej grupie pacjentów. Prezentowana ocena może być dobrym punktem startowym do rozwoju nowych protokołów/narzędzi stosowanych w tak złożonych schorzeniach. Dalsze, szerzej zakrojone badania są potrzebne do zapewnienia pełniejszej i dokładniejszej diagnostyki, co wpłynie na efektywniejsze postępowanie terapeutyczne.

\section{SŁOWA KLUCZOWE}

zespół Cornelii de Lange, funkcjonowanie, fenotyp behawioralny

\section{INTRODUCTION}

Cornelia de Lange syndrome (CdLS, also called Brachmann de Lange syndrome - BdLS) is a congenital multisystem developmental disorder characterized by distinctive facial features, growth and mental retardation, limb abnormalities, and behavioral problems caused by various malformations [1,2]. CdLS is associated with abnormalities on chromosomes 5, 10 and $\mathrm{X}$ : mutations in genes NIPBL, SMC3, SMC1A, RAD21, and HDAC8 are regarded responsible for $70 \%$ of cases $[2,3]$. Genetically CdLS and related phenotypes may be transcriptomopathies [4], while it was previously regarded the most common example of cohesinopathies (disorders of the cohesin complex) [5].

Current diagnosis and therapy is difficult and mainly symptomatic. It requires interdisciplinary efforts. Early and exact diagnosis, including functional assessment, is suggested to establish recommended developmental and therapeutic interventions [1]. Detailed and early functional assessment is a key part of the interdisciplinary approach to CdLS described by Mikołajewska [1] and Parisi et al. (taking into consideration the behavioral phenotype) [2]. The neuropsychological assessment was described by Ajmone et al.: the cognitive abilities of children with CdLS was normal or borderline [6]. Despite efforts of scientists, the review by Mulder et al. showed heterogeneous methodology and quality of the evaluated research, moreover functional assessment was mainly focused on hearing and vision [7]. The aim of the study was twofold: 1) to show the functional status of children with CdLS, 2) to propose a unified protocol/tool for the aforementioned assessment.

\section{MATERIAL AND METHODS}

\section{Material}

Twenty-seven children with CdLS (convenience sample) were assessed in terms of functioning and associated limitations (table I).

\begin{tabular}{|c|c|}
\hline Parameter & Study group $n=27(100 \%)$ \\
\hline \multicolumn{2}{|l|}{ Age [months]: } \\
\hline Mean & 56.11 \\
\hline SD & 32.08 \\
\hline Min & 9.00 \\
\hline Q1 & 33 \\
\hline Q2 (median) & 48 \\
\hline Q3 & 90 \\
\hline $\operatorname{Max}$ & 96 \\
\hline \multicolumn{2}{|c|}{ Age of diagnosis [months]: } \\
\hline Mean & 10.44 \\
\hline SD & 10.01 \\
\hline Min & 1.00 \\
\hline Q1 & 2.00 \\
\hline Q2 (median) & 9.00 \\
\hline Q3 & 15.50 \\
\hline Max & 24.00 \\
\hline \multicolumn{2}{|l|}{ Gender [-]: } \\
\hline M & $12(40 \%)$ \\
\hline $\mathrm{F}$ & $15(60 \%)$ \\
\hline
\end{tabular}

\section{Methods}

The children were assessed using a questionnaire-aided interview (where available) and observational functional assessment.

\section{RESULTS}

Table II presents the results of the functional assessment. Twenty-four basic functional activities were assessed. The most common functional problems were contractures $(88.89 \%)$, deformities $(66.67 \%)$, and torso asymmetry $(66.67 \%)$. 
Table II. Results of functional assessment Tabela II. Wyniki oceny funkcjonalnej

\begin{tabular}{|c|c|}
\hline Presented assessed feature & Prevalence [\%] \\
\hline Eye contact & 100.00 \\
\hline Turning to the sides & 88.89 \\
\hline Sitting & 88.89 \\
\hline Head control & 88.89 \\
\hline Transfer: lying-sitting & 88.89 \\
\hline Contractures & 88.89 \\
\hline Surviving reflexes & 88.89 \\
\hline Kneeling & 77.78 \\
\hline Standing & 77.78 \\
\hline Torso asymmetry & 66.67 \\
\hline Deformities & 66.67 \\
\hline Straight pattern & 66.67 \\
\hline Moves/carries body weight & 55.56 \\
\hline Lower limb dissociation & 55.56 \\
\hline Spasticity & 44.44 \\
\hline Low muscle tone & 33.33 \\
\hline Hypersensitivity to touch & 33.33 \\
\hline Normal muscle tone & 22.22 \\
\hline Improper equilibrium reactions & 22.22 \\
\hline Verbal contact & 22.22 \\
\hline Bend pattern & 11.11 \\
\hline Pathological reflexes & 11.11 \\
\hline
\end{tabular}

\section{DISCUSSION}

This study significantly increases the knowledge concerning functional problems in CdLS. It may also show directions for further clinical research, especially in pediatric neurorehabilitation.

Studies exploring children's functioning and associated problems in a rare disease population (such as CdLS) are scarce due to limited access to resources, reliable information, and support [8]. Careful studies and accurate assessment of the functional abilities are important to understand the developmental challenges for individuals with CdLS and their parents/caregivers. Existing literature suggests differences in the function of children with CdLS. Systematic review of the current understanding of behaviour in CdLS was described by Mulder et al. [7]. CdLS affects multiple organs. Depending on the phenotype (classical or mild), the function of children with CdLS may be influenced by intellectual disability (mild to severe), prenatal and postnatal growth retardation, and congenital anomalies (malformations of the upper limbs, gastrointestinal malformation/rotation, pyloric stenosis, diaphragmatic hernia, heart defects and genitourinary malformations) [3]. The results of the study by Crawford et al. suggest that differences in the social behaviours of children with CdLS may be cognitively mediated rather than subcortically mediated [9]. Anatomical findings by means of computed tomography $(\mathrm{CT})$ and magnetic resonance imaging (MRI) in children with CdLS were reported by Silva-Hernández et al. [10]. The findings by January et al. demonstrate the use of a multispecialty approach to care and complex diagnosis in patients with CdLS [11]. There is need for a standardized tool to assess the development, behaviour, and functional status of children with CdLS. The aforementioned unification may improve understanding of the developmental level of a particular child and planning intervention focused on daily functioning [7]. The limitations of the study constitute: the small sample (it varies from 15 to 378 depending on the study), sample selection (convenience sample), and lack of standardized tools. This study is a pilot study - the aforementioned limitations will be omitted during subsequent stages of the research.

Directions for further research are: research on a larger sample, efforts toward more unified tools and criteria to assess children with CdLS.

CdLS may be characterized by autistic (autism spectrum disorder - ASD) features such as expressive language deficits and excessive repetitive behaviors. The prevalence of ASD symptomatology is high in CdLS [2].

We should take into consideration the fact that most tests on neuropsychological functions have been developed and standardized for typically developing children, thus borderline cognitive abilities may be underemphasized or overemphasized [6]. A huge number of variables with varying measurement levels is needed to describe the CdLS phenotype. Even principal component analysis (PCA) was used to achieve it [12]. The results of previous studies are also difficult to compare due to the heterogeneous assessment methods [7]. Studies on the location and severity of brain abnormalities in CdLS showed abnormal findings on brain MRI (cerebral atrophy, white matter changes, cerebellar hypoplasia, enlarged ventricles, pituitary tumors or cysts, Chiari I malformation, and gliosis. Nevertheless, abnormal behavior can also be observed in patients with CdLS with relatively normal structural brain findings [13]. Laterality and symmetry involvement showed that limb differences in children with CdLS may provide a tool to assist in counseling and prognosis [14]. Anticipatory guidance is needed in aiding parents and staff to individualize care decisions and maximize developmental potential in children with CdLS [15]. Musculoskeletal malformations are usually bilateral (but major ipsilateral malformations were also observed [16]) and may affect mainly the upper limbs ranging from brachyclinodactyly to severe reduction [16]. The tendency to obesity and discrepancy of limb length should also be taken into consideration [17]. Internet network- 
ing may help parents and form future eHealth-related approaches to medical care and psychosocial support in CdLS [8]. Previous studies on frank limb reductions showed that current genetic knowledge is too poor to explain all the cases [18].

To sum up, the outcomes of the study show the functional status of children with CdLS. Even preliminary findings may shape further complementary approaches to the treatment, rehabilitation and care. Moreover the proposed tool was useful.

\section{PIŚMIENNICTWO}

1. Mikołajewska E. Interdisciplinary therapy in Cornelia de Lange syndrome review of the literature. Adv. Clin. Exp. Med. 2013; 22(4): 571-577.

2. Parisi L., Di Filippo T., Roccella M. Behavioral Phenotype and Autism Spectrum Disorders in Cornelia de Lange Syndrome. Ment. Illn. 2015; 7(2): 5988. 3. Boyle M.I., Jespersgaard C., Brøndum-Nielsen K., Bisgaard A.M., Tümer Z. Cornelia de Lange syndrome. Clin. Genet. 2015; 88(1): 1-12, doi: 10.1111/ cge. 12499 .

4. Yuan B., Pehlivan D., Karaca E., Patel N., Charng W.L., Gambin T., Gonzaga-Jauregui C., Sutton V.R., Yesil G., Bozdogan S.T., Tos T., Koparir A., Koparir E., Beck C.R., Gu S., Aslan H., Yuregir O.O., Al Rubeaan K., Alnaqeb D., Alshammari M.J., Bayram Y., Atik M.M., Aydin H., Geckinli B.B., Seven M., Ulucan H., Fenercioglu E., Ozen M., Jhangiani S., Muzny D.M., Boerwinkle E., Tuysuz B., Alkuraya F.S., Gibbs R.A., Lupski J.R. Global transcriptional disturbances underlie Cornelia de Lange syndrome and related phenotypes. J. Clin. Invest. 2015; 125(2): 636-651, doi: 10.1172/JCI77435.

5. Kline A.D., Calof A.L., Lander A.D., Gerton J.L., Krantz I.D., Dorsett D., Deardorff M.A., Blagowidow N., Yokomori K., Shirahige K., Santos R., Woodman J., Megee P.C., O‘Connor J.T., Egense A., Noon S., Belote M., Goodban M.T., Hansen B.D., Timmons J.G., Musio A., Ishman S.L., Bryan Y., Wu Y., Bettini L.R., Mehta D., Zakari M., Mills J.A., Srivastava S., Haaland R.E. Clinical, developmental and molecular update on Cornelia de Lange syndrome and the cohesin complex: abstracts from the 2014 Scientific and Educational Symposium. Am. J. Med. Genet. A. 2015; 167(6): 1179-1192, doi: 10.1002/ ajmg.a.37056.

6. Ajmone P.F., Rigamonti C., Dall'Ara F., Monti F., Vizziello P., Milani D., Cereda A., Selicorni A., Costantino A. Communication, cognitive development and behavior in children with Cornelia de Lange Syndrome (CdLS): preliminary results. Am. J. Med. Genet. B. Neuropsychiatr. Genet. 2014; 165B(3) 223-229, doi: 10.1002/ajmg.b.32224.

7. Mulder P.A., Huisman S.A., Hennekam R.C., Oliver C., van Balkom I.D., Piening S. Behaviour in Cornelia de Lange syndrome: a systematic review. Dev. Med. Child. Neurol. 2017; 57(4): 361-366, doi: 10.1111/dmcn.13361.

8. Cacioppo C.N., Conway L.J., Mehta D., Krantz I.D., Noon S.E. Attitude about the use of internet support groups and the impact among parents of children with Cornelia de Lange syndrome. Am. J. Med. Genet. C. Semin. Med. Genet. 2016; 172(2): 229-236, doi: 10.1002/ajmg.c.31504.

9. Crawford H., Moss J., McCleery J.P., Anderson G.M., Oliver C. Face scanning and spontaneous emotion preference in Cornelia de Lange syndrome and Rubinstein-Taybi syndrome. J. Neurodev. Disord. 2015; 7(1): 22, doi: 10.1186/ s11689-015-9119-4.

10. Silva-Hernández F., Rodríguez-Cuadrado G.I., Martin-Ruaigip R.J., Barreras-Ávila L., González-Chevere B., Valentin-Rivera R., Labat-Alvarez E.

\section{CONCLUSIONS}

This study could be a good starting point to develop new protocols/tools applicable to such complex diseases. Moreover further and wider studies are needed in order to enable a more complete and accurate assessment, thereby ensuring more efficient treatment plans.
Functional Brain Imaging in Cornelia de Lange Syndrome: Case Report and Literature review. Bol. Asoc. Med. P R. 2015; 107(2): 73-77.

11. January K., Conway L.J., Deardorff M., Harrington A., Krantz I.D., Loomes K., Pipan M., Noon S.E. Benefits and limitations of a multidisciplinary approach to individualized management of Cornelia de Lange syndrome and related diagnoses. Am. J. Med. Genet. C. Semin. Med. Genet. 2016; 172(2): 237-245.

12. Wulffaert J., van Berckelaer-Onnes I., Kroonenberg P., Scholte E., Bhuiyan Z., Hennekam R. Simultaneous analysis of the behavioural phenotype, physical factors, and parenting stress in people with Cornelia de Lange syndrome. J. Intellect. Disabil. Res. 2009; 53(7): 604-619, doi: 10.1111/j.1365$-2788.2009 .01185 . \mathrm{x}$.

13. Roshan Lal T.R., Kliewer M.A., Lopes T., Rebsamen S.L., O’Connor J., Grados M.A., Kimball A., Clemens J., Kline A.D. Cornelia de Lange syndrome: Correlation of brain MRI findings with behavioral assessment. Am. J. Med. Genet. C. Semin. Med. Genet. 2016; 172(2): 190-197, doi: 10.1002/ ajmg.c. 31503 .

14. Mehta D., Vergano S.A., Deardorff M., Aggarwal S., Barot A., Johnson D.M., Miller N.F., Noon S.E., Kaur M., Jackson L., Krantz I.D. Characterization of limb differences in children with Cornelia de Lange Syndrome. Am. J. Med. Genet. C. Semin. Med. Genet. 2016; 172(2): 155-162, doi: 10.1002/ ajmg.c. 31498 .

15. Kline A.D., Krantz I.D., Sommer A., Kliewer M., Jackson L.G., FitzPatrick D.R., Levin A.V., Selicorni A. Cornelia de Lange syndrome: clinical review, diagnostic and scoring systems, and anticipatory guidance. Am. J. Med. Genet. A. $2007 ; 143 \mathrm{~A}(12)$ : $1287-1296$

16. Baquero-Montoya C., Gil-Rodríguez M.C., Hernández-Marcos M., Teresa-Rodrigo M.E., Vicente-Gabas A., Bernal M.L., Casale C.H., Bueno-Lozano G., Bueno-Martínez I., Queralt E., Villa O., Hernando-Davalillo C., Armengol L., Gómez-Puertas P., Puisac B., Selicorni A., Ramos F.J., Pié J. Severe ipsilateral musculoskeletal involvement in a Cornelia de Lange patient with a novel NIPBL mutation. Eur. J. Med. Genet. 2014; 57(9): 503-509, doi: 10.1016/j. ejmg.2014.05.006

17. Mariani M., Decimi V., Bettini L.R., Maitz S., Gervasini C., Masciadri M., Ajmone P., Kullman G., Dinelli M., Panceri R., Cereda A., Selicorni A. Adolescents and adults affected by Cornelia de Lange syndrome: A report of 73 Italian patients. Am. J. Med. Genet. C. Semin. Med. Genet. 2016; 172(2): 206-213, doi: 10.1002/ajmg.c.31502.

18. Lopez-Burks M.E., Santos R., Kawauchi S., Calof A.L., Lander A.D. Genetic enhancement of limb defects in a mouse model of Cornelia de Lange syndrome. Am. J. Med. Genet. C. Semin. Med. Genet. 2016; 172(2): 146-154, doi: 10.1002/ajmg.c.31491 